\title{
Antinutrient and Mineral Content of Thirteen Different Varieties of Pearl Millet Locally Grown in Haryana, India
}

\author{
Isha Kaushik* and Raj Bala Grewal \\ Centre of Food Science and Technology, CCSHAU, Hisar, Haryana, India \\ *Corresponding author
}

\section{A B S T R A C T}

Thirteen different varieties of pearl millet locally grown in Haryana were analyzed

\begin{tabular}{|l|}
\hline Ke y w or d s \\
Antinutrient, \\
$\begin{array}{l}\text { Polyphenol, } \\
\text { Phytic acid, } \\
\text { Pearl millet }\end{array}$ \\
\hline Article Info \\
\hline $\begin{array}{l}\text { Accepted: } \\
\text { 19 April 2017 } \\
\text { Available Online: } \\
\text { 10 May 2017 }\end{array}$ \\
\hline
\end{tabular}

for antinutrient content (polyphenol and phytic acid) and mineral content. Significant variation was noticed among different varieties i.e., 403.7 to $521 \mathrm{mg}$ polyphenol/100 g and 577.7 to 620.7 mgphytic acid/100 g. Polyphenol and phytic acid was found maximum in HHB-146 and HHB-67 and minimum content observed in WHC-901-445 and HHB-226, respectively varieties of pearl millet. Pearl millet varieties were also contained appreciable amount of mineral content i.e., potassium, magnesium, calcium, iron, zinc and copper varied from 171.6 to $215.3,64.1$ to $72.0,27.2$ to $37.3,2.7$ to $6.4,1.3$ to 1.9 and 0.1 to $0.5 \mathrm{mg} / 100 \mathrm{~g}$, respectively. Different treatments such as soaking, fermentation, blanching and roasting can enhance the bio-availability of these minerals by decreasing the level of antinutrients. Therefore, knowledge of nutrient content of these locally grown pearl millet varieties may help in the commercial processing of these grains into value-added food and beverage products which can be an important driver for economy and to curb malnutrition in developing countries.

\section{Introduction}

Pearl millet is small seeded grains, mainly produced in tropical and semi-arid region in India and Africa. It is underutilized and lesser known crop with capability of growing in less water areas on about 30 million ha in more than 30 countries of five continents viz., Asia, Africa, North America, South America, and Australia. India is the largest producer of the pearl millet in the world and its cultivation is next to rice, maize and wheat. The major pearl millet growing states in order of area are Rajasthan, Maharashtra, Gujarat, Uttar Pradesh and Haryana and these account for $87 \%$ of the total area under cultivation of pearl millet (Rana et al., 2012). In Haryana, production area under this crop during karif2014-15 was 383 hectare with total production of 670 lakh tonnes and average yield of $1749 \mathrm{kgs} / \mathrm{ha}$ (Anonymous, 2015). It is cheap and economic crop of dual purpose which is used as food for human, feed for poultry birds and also dry as well as green fodder for cattle. Pearl millet commonly known as bajra and termed as "nutricereal" due to rich source of energy, carbohydrate, protein, fat and ash, besides, it is also a rich source of dietary fiber and minerals (iron, calcium, magnesium, potassium etc) (Abdalla 
et al., 2009). It is free from major antinutrients but contains variable amount of phytate and polyphenols and different treatments such as soaking, fermentation, blanching and roasting decrease the level of these antinutrients (Eyzaguirre et al., 2006; Hithamani \& Srinivasan, 2014; Lestienne et al., 2005). In developing countries, the commercial processing of these locally grown grains into value-added food and beverage products can be an important driver for economy and to curb malnutrition, therefore, the objective of this study to analyze the antinutrient and mineral content of thirteen pearl millet varieties.

\section{Materials and Methods}

Pearl millet varieties viz., composite/desi varieties (HC-10 and HC-20), improved released variety (HHB-67), released hybrids (HHB-146, HHB-197, HHB-223, HHB-226, HHB-234 and HHB-272), white composite variety (WHC-901-445), white seeded hybrid (HMP-802 and HHB-256) and hybrid in pipeline (HHB-265) were procured from the Department of Genetics and Plant Breeding, CCSHAU, Hisar.

The chemicals were procured from SigmaAldrich Chemicals Pvt. Ltd. New Delhi (India) and Central Drug House (CDH), New Delhi (India).

\section{Anti-nutrient content of pearl millet}

\section{Polyphenols}

The polyphenols were determined by the method of Swain \& Hills (1959). About 500 mg of defatted sample was refluxed with 50 $\mathrm{ml}$ methanol containing $1 \% \mathrm{HCl}$ for $4 \mathrm{hr}$. The extract was concentrated by evaporating methanol on a boiling water bath and brought its volume to $25 \mathrm{ml}$ with methanolic- $\mathrm{HCl}$. The extract $(1.5 \mathrm{ml})$ was diluted with water to 8.5 $\mathrm{ml}$ in $10 \mathrm{ml}$ graduated test tube. The contents were well mixed. Then, $0.5 \mathrm{ml}$ Folin-Denis reagent was added and the tubes were thoroughly shaken. Exactly after $3 \mathrm{~min} ., 1 \mathrm{ml}$ saturated sodium carbonate solution was added and the tubes were thoroughly shaken again and allowed to stand for $1 \mathrm{hr}$. The absorbance was read at $725 \mathrm{~nm}$ using methanolic- $\mathrm{HCl}$ as blank. If the solution was cloudy or precipitates appeared, it was centrifuged before readings were taken. A standard curve was plotted by taking $0.5 \mathrm{ml}$ to $4.0 \mathrm{ml}$ of tannic standard solution containing $10 \mu \mathrm{g}$ to $80 \mu \mathrm{g}$ of tannic acid.

$$
\text { Polyphenol }(\mathrm{mg} / 100 \mathrm{~g})=\frac{\mathrm{M} \times \mathrm{V} \times 100}{\mathrm{~W} \times \mathrm{V}_{1} \times 1000}
$$

Where,

$\mathrm{M}=$ concentration of extract elute obtained from standard graph

$\mathrm{V}=$ volume made of extract $(\mathrm{ml})$

$\mathrm{V} 1=$ volume of aliquot $(\mathrm{ml})$

$\mathrm{W}=$ weight of sample $(\mathrm{g})$

\section{Phytic acid}

Phytic acid was estimated using method of Haug \& Lantzsch (1983). About $1 \mathrm{~g}$ finely ground sample was extracted with $25 \mathrm{ml} 0.2$ $\mathrm{N} \mathrm{HCl}$ for $3 \mathrm{hr}$ with continuous shaking in a shaker. After proper shaking, it was filtered through Whatmann No.1 filter paper. The volume was made to $25 \mathrm{ml}$ with $0.2 \mathrm{~N} \mathrm{HCl}$. Then $0.5 \mathrm{ml}$ of the sample extract was pipetted into a test tube. One $\mathrm{ml}$ ferric ammonium sulphate solution was added. The tube was heated in a boiling water bath for 30 min. The contents of the tube were mixed and centrifuged for $30 \mathrm{~min}$. at $3000 \mathrm{rpm}$. $1 \mathrm{ml}$ supernatant was transferred to another test tube and $1.5 \mathrm{ml}$ bipyridine solution was added. The absorbance at $519 \mathrm{~nm}$ against distilled water was measured. For plotting a standard curve, different concentrations i.e. 
0.2-1.0 $\mathrm{ml}$ of standard sodium phytate solution containing 40-200 $\mu \mathrm{g}$ phytic acid were taken and made to $1.4 \mathrm{ml}$ with water.

$$
\text { Phytic acid }(\mathrm{mg} / 100 \mathrm{~g})=\frac{\mathrm{M} \times \mathrm{V} \times 100}{\mathrm{~W} \times \mathrm{V}_{1} \times 1000}
$$

Where,

$\mathrm{M}=$ concentration of extract elute obtained from standard graph

$\mathrm{V}=$ volume made of extract $(\mathrm{ml})$

$\mathrm{V} 1=$ volume of aliquot $(\mathrm{ml})$

$\mathrm{W}=$ weight of sample $(\mathrm{g})$

\section{Mineral estimation}

Minerals were estimated by using the MPAES unit (Microwave plasma-atomic emission spectroscopy, Model No. 4100 Agilent Technology). $1 \mathrm{~g}$ pearl millet flour was digested with $10 \mathrm{ml}$ of $35 \%$ nitric oxide into digestion tubes. Samples were digested according to the ascending order of the temperature: first digested at $800 \mathrm{C}$ for 20 min., then $1200 \mathrm{C}$ for $30 \mathrm{~min} ., 140$ 0C for 50 min. and $1450 \mathrm{C}$ for 5 minute. After digestion, samples were made volume up to $100 \mathrm{ml}$ with distilled water. Take $10 \mathrm{ml}$ for running the sample into MP-AES unit which automatically read the sample and give the concentration (ppm) of required mineral estimation.

\section{Results and Discussion}

\section{Polyphenol content}

In millet, several phenolic compounds are primarily located in the grain outer layers and can be distinguished such as phenolic acids, flavonoids and condensed polymeric phenols, also known as tannins. Tannins are polymers resulting from the condensation of flavan-3ols (Eyzaguirre et al., 2006), form complex with protein, carbohydrates, and minerals and thus reduce digestibility of these nutrients
(Dyke \& Rooney, 2006). Phenolics may also contribute colour to pericarp (Mcdonough \& Rooney, 1989) which impart undesirable colours in grain products during food processing. Several methods for decreasing the tannins in pearl millet viz., milling/decortication (Lestinne et al., 2005), cooking (Nambiar et al., 2012), fermentation (Eltayeb et al., 2007), germination (Hithamani \& Srinivasan, 2014) and chemical treatment (Beta et al., 2000) have been documented. Different varieties of pearl millet studied contained 403.7 to $521 \mathrm{mg}$ polyphenol/100 g (Table 1). Lowest polyphenol content was noticed in WHC-901445 and highest in HHB-146 variety. No significant difference in polyphenol content was noticed between HHB-146 and HHB-226 varieties. Polyphenol content of other varieties except HHB-67 and HHB-197 was found significantly lower than HHB-226. Variation in polyphenol content (608-788, 741.29 to 767.54 and 502.78 to 658.30 $\mathrm{mg} / 100 \mathrm{~g}$ ) has been reported by Sharma \& Kapoor (1996), Archana et al., (1998) and Sangwan (2005). Perusals of data indicate that White seeded variety has low content of polyphenol than other varieties and this is positively correlated to its colour. Similar reports have been documented which states that dark varieties have high polyphenol content than light (Walter \& Marchesan, 2011, Li et al., 2015). This variation in polyphenols may be associated to various factors such as genotypic effect, degree of maturity and environment effect (Radhouane \& Fattouch, 2009).

\section{Phytic acid content}

Phytate (myoinositol 1, 2 3, 5, 6-hexakis insitoldihydrogen phosphate) is a naturally occuring organic compound in plant seed coat and germ (Mahgoub \& Elhag, 1998). Phytic acid is known as the major source of phosphorus, comprising $1-5 \%$ by weight in 
cereals (Vats \& Banerjee, 2004). Beside its nourishment, pearl millet contain significant amount of inositol hexaphosphate (IP6) which is generally considered as antinutritional factor affecting the bioavailability of minerals (Ca, P, Fe, Zn) (Eltayeb et al., 2007). Different treatments such as milling (Sridevi et al., 2011), fermentation (Eltayeb et al., 2007) and blanching (Archana et al.,1998) decrease the level of phytic acid in pearl millet. Phytic acid content ranged from 577.7 to $620.7 \mathrm{mg} / 100 \mathrm{~g}$ in different varieties of pearl millet (Table 1). HHB-67 contained highest phytic acid content followed by HHB223, WHC-901-445, HHB-197, HC-10, HHB-265, HHB-272, HHB-226, HC-20, HMP-802, HHB-146, HHB-256 and HHB234 variety. No significant difference in phytic acid content was observed between
HHB-67, HHB-223 and WHC-901-445 varieties. HHB-234 variety contained significantly lower phytic acid content than other varieties of pearl millet. Chaudhary (2011) and Sihag et al., (2015) reported (697.5-789.4 and $683.1 \mathrm{mg} / 100 \mathrm{~g}$ ) phytic acid content, respectively in different varieties of pearl millet. Sangwan (2005) also noticed highest content of phytic acid in HHB-67 variety among twelve different varieties of pearl millet. Whereas high content of phytic acid in pearl millet grain was documented by Chaudhary (2011), Gull et al., (2015) and Sihag et al.,(2015). Perusals of data indicate variation in phytic acid content varies which may be due to difference in genotype and growing season (Radhouane \& Fattouch, 2009).

Figure.1 Mineral content of flour of different pearl millet varieties

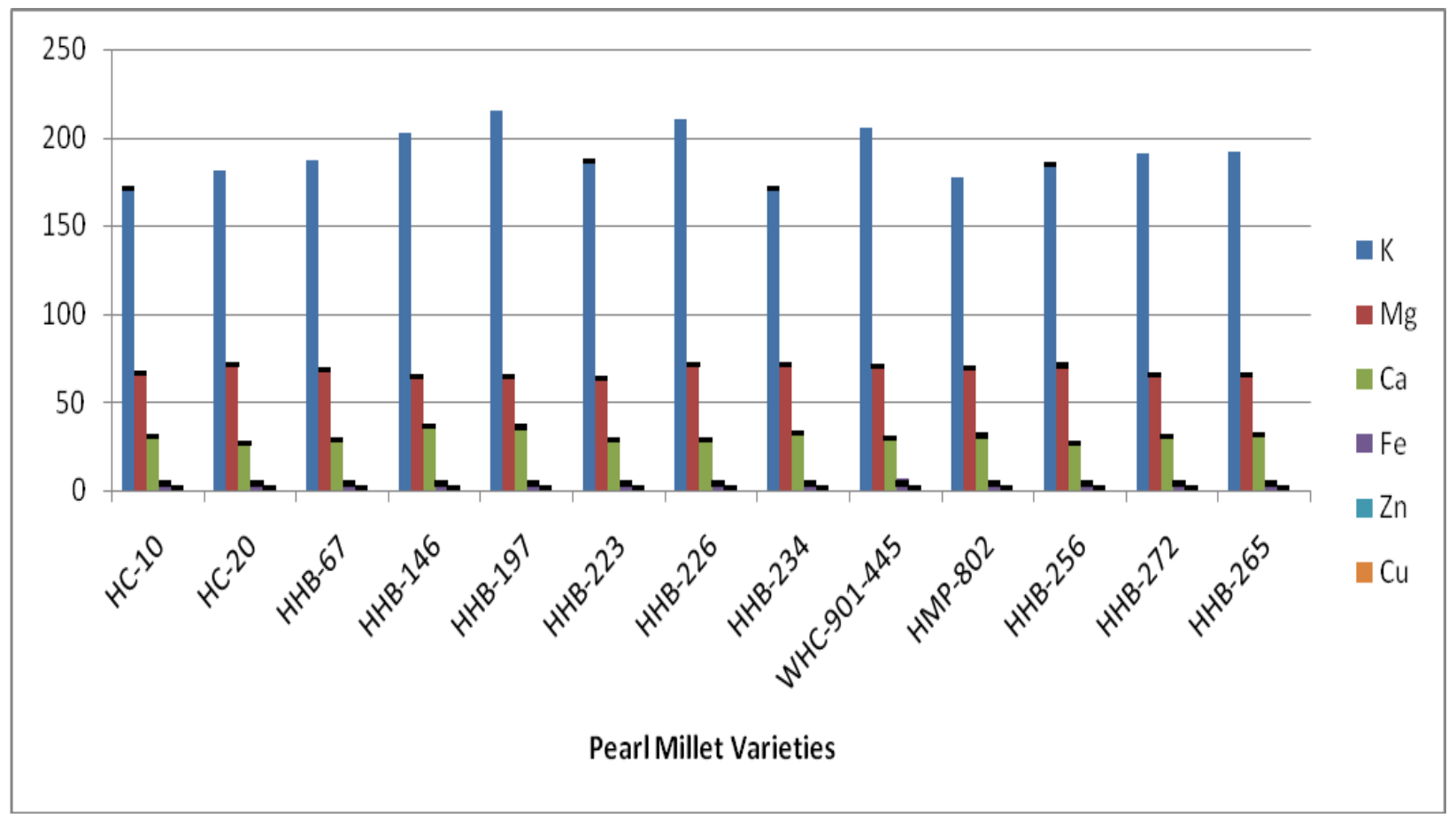


Table.1 Antinutrient (mg/100g on dry matter basis) of flour of different pearl millet varieties

\begin{tabular}{lll}
\hline Pearl millet varieties & Polyphenols & Phytic acid \\
\hline HC-10 & $418.3 \pm 4.9_{\mathrm{g}}$ & $604.0 \pm 4.00_{\mathrm{cd}}$ \\
HC-20 & $448.1 \pm 4.4_{\mathrm{e}}$ & $593.0 \pm 3.61_{\mathrm{fg}}$ \\
HHB-67 & $505.4 \pm 5.8_{\mathrm{bc}}$ & $620.7 \pm 3.06_{\mathrm{a}}$ \\
HHB-146 & $521.0 \pm 4.0_{\mathrm{a}}$ & $589.3 \pm 4.04_{\mathrm{g}}$ \\
HHB-197 & $501.0 \pm 4.0_{\mathrm{c}}$ & $605.0 \pm 3.61_{\mathrm{c}}$ \\
HHB-223 & $439.0 \pm 7.0_{\mathrm{f}}$ & $618.3 \pm 3.06_{\mathrm{a}}$ \\
HHB-226 & $510.0 \pm 3.5_{\mathrm{b}}$ & $597.7 \pm 2.52_{\mathrm{ef}}$ \\
HHB-234 & $445.7 \pm 5.4_{\mathrm{ef}}$ & $577.7 \pm 2.52_{\mathrm{i}}$ \\
WHC-901-445 & $403.7 \pm 5.1_{\mathrm{h}}$ & $612.3 \pm 3.06_{\mathrm{b}}$ \\
HMP-802 & $461.0 \pm 3.1_{\mathrm{d}}$ & $590.3 \pm 2.52_{\mathrm{g}}$ \\
HHB-256 & $416.1 \pm 4.4_{\mathrm{g}}$ & $583.3 \pm 2.00_{\mathrm{h}}$ \\
HHB-272 & $411.7 \pm 2.8_{\mathrm{gh}}$ & $599.7 \pm 2.08_{\mathrm{de}}$ \\
HHB-265 & $451.9 \pm 5.3_{\mathrm{e}}$ & $603.0 \pm 2.00_{\mathrm{cd}}$ \\
\hline
\end{tabular}

Values indicate the mean \pm SDoftriplicates; Different superscripts in the same column mean significant difference at $\mathrm{p}<0.05$

Table.2 Mineral content (mg/100g on dry matter basis) of flour of different pearl millet varieties

\begin{tabular}{lllllll}
\hline $\begin{array}{l}\text { Pearl millet } \\
\text { varieties }\end{array}$ & Potassium & Magnesium & Calcium & Iron & Zinc & Copper \\
\hline HC-10 & $171.6 \pm 0.50$ & $67.3 \pm 0.02$ & $31.0 \pm 0.03$ & $6.1 \pm 0.01$ & $1.9 \pm 0.01$ & $0.4 \pm 0.01$ \\
HC-20 & $181.3 \pm 0.04$ & $71.6 \pm 0.08$ & $27.2 \pm 0.03$ & $4.6 \pm 0.01$ & $1.4 \pm 0.01$ & $0.1 \pm 0.01$ \\
HHB-67 & $187.4 \pm 0.14$ & $69.1 \pm 0.08$ & $29.1 \pm 0.07$ & $5.9 \pm 0.01$ & $1.9 \pm 0.01$ & $0.3 \pm 0.01$ \\
HHB-146 & $202.2 \pm 0.02$ & $65.5 \pm 0.02$ & $37.3 \pm 0.03$ & $3.0 \pm 0.01$ & $1.8 \pm 0.01$ & $0.3 \pm 0.01$ \\
HHB-197 & $215.3 \pm 0.08$ & $64.7 \pm 0.04$ & $36.5 \pm 0.04$ & $2.7 \pm 0.00$ & $1.4 \pm 0.01$ & $0.3 \pm 0.01$ \\
HHB-223 & $186.8 \pm 0.25$ & $64.1 \pm 0.11$ & $29.1 \pm 0.04$ & $4.0 \pm 0.00$ & $1.4 \pm 0.01$ & $0.3 \pm 0.01$ \\
HHB-226 & $210.3 \pm 0.09$ & $72.0 \pm 0.05$ & $29.5 \pm 0.05$ & $2.8 \pm 0.01$ & $1.7 \pm 0.01$ & $0.3 \pm 0.00$ \\
HHB-234 & $171.6 \pm 0.50$ & $71.6 \pm 0.13$ & $32.8 \pm 0.03$ & $3.6 \pm 0.00$ & $1.9 \pm 0.01$ & $0.4 \pm 0.01$ \\
WHC-901- & $205.4 \pm 0.18$ & $71.0 \pm 0.12$ & $30.1 \pm 0.04$ & $6.4 \pm 0.01$ & $1.9 \pm 0.01$ & $0.5 \pm 0.01$ \\
$\mathbf{4 4 5}$ & & & & & & \\
HMP-802 & $177.8 \pm 0.08$ & $69.7 \pm 0.04$ & $31.7 \pm 0.04$ & $3.3 \pm 0.00$ & $1.8 \pm 0.01$ & $0.5 \pm 0.02$ \\
HHB-256 & $184.7 \pm 0.19$ & $71.4 \pm 0.13$ & $27.6 \pm 0.05$ & $4.5 \pm 0.01$ & $1.4 \pm 0.01$ & $0.3 \pm 0.01$ \\
HHB-272 & $190.8 \pm 0.23$ & $65.9 \pm 0.06$ & $31.5 \pm 0.05$ & $4.0 \pm 0.01$ & $1.7 \pm 0.01$ & $0.5 \pm 0.01$ \\
HHB-265 & $191.9 \pm 0.14$ & $66.4 \pm 0.07$ & $32.3 \pm 0.03$ & $4.0 \pm 0.00$ & $1.7 \pm 0.01$ & $0.5 \pm 0.01$ \\
CD at 5 \% & $\mathbf{0 . 1 4}$ & $\mathbf{0 . 0 7}$ & $\mathbf{0 . 0 4}$ & $\mathbf{0 . 0 1}$ & $\mathbf{0 . 0 1}$ & $\mathbf{0 . 0 1}$ \\
level & & & & & & \\
\hline Vat & & & & & & \\
\hline
\end{tabular}

Values indicate the mean \pm SD of triplicates 


\section{Mineral content}

Potassium, magnesium, calcium, iron, zinc and copper ranged from 171.6 to $215.3,64.1$ to $72.0,27.2$ to $37.3,2.7$ to $6.4,1.3$ to 1.9 and 0.1 to $0.5 \mathrm{mg} / 100 \mathrm{~g}$ respectively (Table 2 ). Maximum potassium, magnesium and calcium was observed in released hybrids HHB-197, HHB-226 and HHB-146, respectively and minimum in composite varieties $\mathrm{HC}-10, \mathrm{HC}-20$ and released hybrid HHB-223 variety, respectively. Balseiro et al., (2014), Thilagavathi et al., (2015) and Marmouzi et al., (2016) reported high range $(6.56 \mathrm{mg} / 100 \mathrm{~g}, 39.63 \mathrm{mg} / 100 \mathrm{~g}$ and 211 $\mathrm{mg} / 100 \mathrm{~g}$ ) calcium in pearl millet grain than present study. Whereas Abdalla et al., (2010) and Maktouf et al., (2016) reported low value $(16-23 \mathrm{mg} / 100 \mathrm{~g})$ of calcium in pear millet. The results of present study are in accordance to those reported by Abdalla et al., (1998) and Nithiya et al., (2006). According to Sangwan (2005) and Marmouzi et al., (2016), pearl millet contained 132.40-166.80 and 174 $\mathrm{mg} / 100 \mathrm{~g}$ magnesium.

The present findings of investigation reported maximum iron $(6.4 \mathrm{mg} / 100 \mathrm{~g})$, zinc (1.9 $\mathrm{mg} / 100 \mathrm{~g})$ and copper $(0.5 \mathrm{mg} / 100 \mathrm{~g})$ in white composite (WHC-901-445) variety of pearl millet. Hama et al., (2011) also found 4.51 $\mathrm{mg} / 100 \mathrm{~g}$ iron content in pearl millet grain which is comparable to our present results. On the contrary, Abdalla et al., (2010) and Chaudhary (2011) reported higher iron content in pearl millet varieties ranging from $17.88-18.65$ and $10.30-11.49 \mathrm{mg} / 100 \mathrm{~g}$, respectively. Results of zinc are comparable to those reported by Hama et al., (2011) who noticed (1.80-2.02 $\mathrm{mg} / 100 \mathrm{~g})$ zinc in pearl millet whereas Sridevi et al., (2011) reported low value of zinc $(0.73 \mathrm{mg} / 100 \mathrm{~g})$ in pearl millet grain. On the contrary, Abdalla et al., (2010) and Chaudhary (2011) documented high content of zinc (6.7-7.29 and 4.47-5.29 $\mathrm{mg} / 100 \mathrm{~g}$, respectively) in pearl millet varieties. Results of copper content are in agreement to results studied by Sridevi et al., (2011) and Thilagavathi et al., (2015). Abdel Rahaman et al., (2007) studied high range $(0.85-1.46 \mathrm{mg} / 100 \mathrm{~g})$ total copper content in pearl millet cultivars. Variation in mineral content may be due to genotypic and season effect, and extraction method.

In conclusion it was found that significant variation exist in polyphenol and phytic acid content of thirteen different varieties of pearl millet. Significant amount of different minerals was also present in these varieties of Haryana with good chemical composition as presented in Figure 1. With opting good processing treatments such as malting, roasting, blanching to decrease the level of such antinutrients, can make pearl millet crop better to curb malnutrition problems. As pearl millet is cheap and underutilized crop of Haryana, such knowledge may help the food processors, researchers, and scientist to develop the food products which may lead to diversification in marketing to boost up Indian economy.

\section{Acknowledgements}

The authors are grateful to Indian Agricultural Research Institute (IARI), Delhi for the technical assistance.

\section{References}

Abdalla, A.A., Ahmed, I.A. \& El-Tinay, A.H. 2010. Influence of traditional processing on minerals $\mathrm{HCl}$-extractability of pearl millet. J. Agri. Biol. Sci., 6(4): 530-534.

Abdalla, A.A., Anmed, U.H., Ahmed, A.R., ElTinay, A.H. \& Ibrahim, K.A. 2009. Physicochemical characterization of traditionally extracted pearl millet starches. J. Appl. Sci. Res., 5(11): 20162027

Abdalla, A.A., Tinay, A.H., Mohamed, B.E. \& Abdalla, A.H. 1998. Proximate 
composition, starch, phytate and mineral contents of ten pearl millet genotypes. Food Chem., 63(2): 243-246.

Abdelrahaman, S., Elmaki, H., Idris, W., Hassan, A., Babiker, E. \& El Tinay, A. 2007. Antinutritional factor content and hydrochloric acid extractability of minerals in pearl millet cultivars as affected by germination. Int. J. Food Sci. Nutri., 58(1): 6-17.

Anonymous. 2015. http://www.agriharyana.nic.in/Stat_Info/F inal estimates.

Archana, Sehgal, S. and Kawatra, A. 1998. Reduction of polyphenol and phytic acid content of pearl millet grains by malting and blanching. Plant Foods for Human Nutrition, 53(2): 93-98.

Balseiro, G., Taron, A. \& Garcia-Zapateiro, L. 2014. Nutritional properties of different composite flours from maize (Zea mays. variety ica v109 and pearl millet (Pennisetum glaucum. malted with calcium chloride and gibberellic acid. European Food Res. Technol., 240(3): 471-475.

Beta, T., Corke, H., Rooney, L. \& Taylor, J. 2000. Starch properties as affected by sorghum grain chemistry. J. Sci. Food and Agri., 81(2): 245-251.

Chaudhary, G. 2011. Nutritional evaluation of white and grey pearl millet varieties and their utilization for product development. M.Sc. Thesis. CCS Haryana Agricultural University, Hisar. India.

Dykes, L. \& Rooney, L. 2006. Sorghum and millet phenols and antioxidants. J. Cereal Sci., 44(3): 236-251.

Eltayeb, M.M., Babiker, E.E., Hassn, B.A. \&Sulieman, A.M. 2007. Effect of processing followed by fermentation on antinutritional factors content of pearl millet (Pennisetum glaucum L). cultivars. Pakistan J. Nutri., 6(5): 463-467.

Eyzaguirre, R., Nienaltowska, K., de Jong, L., Hasenack, B. \&Nout, M. 2006. Effect of food processing of pearl millet (Pennisetumglaucum. IKMP-5 on the level of phenolics, phytate, iron and zinc. J. Sci. Food and Agri., 86(9): 1391-1398.

Gull, A., Prasad, K. \& Kumar, P. 2015. Evaluation of functional, antinutritional, pasting and microstructural properties of Millet flours. J. Food Measurement and Characterization, 10(1): 96-102.

Hama, F., Icard-Vernière, C., Guyot, J., Picq, C., Diawara, B. \&Mouquet-Rivier, C. 2011. Changes in micro- and macronutrient composition of pearl millet and white sorghum during in field versus laboratory decortication. J. Cereal Sci., 54(3): 425-433.

Haug, W. \& Lantzsch, H. 1983. Sensitive method for the rapid determination of phytate in cereals and cereal products. $J$. Sci. Food and Agri., 34(12): 1423-1426.

Hithamani, G. \& Srinivasan, K. 2014. Effect of domestic processing on the polyphenol content and bioaccessibility in finger millet (Eleusinecoracana. and pearl millet (Pennisetumglaucum. Food Chem., 164: 55-62.

Lestienne, I., Mouquet-Rivier, C., IcardVerniere, C., Rochette, I. \& Treche, S. 2005. The effects of soaking of whole, dehulled and ground millet and soybean seeds on phytate degradation and Phy/Fe and Phy/Zn molar ratios. Int. J. Food Sci. Technol., 40(4): 391-399.

Li, Y., Ma, D., Sun, D., Wang, C., Zhang, J., Xie, Y. \& Guo, T. 2015. Total phenolic, flavonoid content, and antioxidant activity of flour, noodles, and steamed bread made from different colored wheat grains by three milling methods. The Crop J., 3(4): 328-334.

Mahgoub, S. \& Elhag, S. 1998. Effect of milling, soaking, malting, heat-treatment and fermentation on phytate level of four Sudanese sorghum cultivars. Food Chem., 61(1-2): 77-80.

Maktouf, S., Jeddou, K., Moulis, C., Hajji, H., Remaud-Simeon, M. \&Ellouz-Ghorbel, R. 2016. Evaluation of dough rheological properties and bread texture of pearl millet-wheat flour mix. J. Food Sci. Technol., 53(4): 2061-2066. 
Marmouzi, I., Ali, K., Harhar, H., Gharby, S., Sayah, K. \& El Madani, N. 2016. Functional composition, antibacterial and antioxidative properties of oil and phenolics from Moroccan Pennisetumglaucum seeds. J. Saudi Soc. Agri. Sci., Article in press.

McDonough, C. \& Rooney, L. 1989. Structural characteristics of pennisetumamericanum (pearl millet. using scanning electron and fluorescence microscopy. Food Structure, 8(1): 1-14.

Nambiar, V.S., Sareen, N., Daniel, M. \& Gallego, E.B. 2012. Flavonoids and phenolic acids from pearl millet (Pennisetumglaucum. based foods and their functional implications. Functional Foods in Health and Dis., 2(7): 251-264.

Nithya, K.S., Ramachandramurty, B. \&Krishnamoorthy, V.V. 2006. Assessment of antinutritional factors, mineral and enzyme activities of the traditional (CO-7. and hybrid (Cohcu-B. pearl millet (Pemnisetumglaucum. as influenced by different processing methods. J. Appl. Sci. Res., 2(12): 11641168.

Radhouane, L. \& Fattouch, S. 2009. Biochemical investigation of tunisian autochthonous pearl millet ecotypes. Sjemenarstvo, 26: 3-4.

Rana, K., Kumar, D. \& Bana, R. 2012. Agronomic research on pearl millet (Pennisetumglaucum. Indian J. Agron., 57(3): 45-57.

Sangwan, A. 2005. Nutritional evaluation and product development from white and yellow pearl millet varieties.M.Sc. Thesis.
CCS Haryana Agricultural University, Hisar, India.

Sharma, A. \& Kapoor, A. 1996. Levels of antinutritional factors in pearl millet as affected by processing treatments and various types of fermentation. Plant Foods for Human Nutrition, 49(3): 241252.

Sihag, M., Sharma, V., Goyal, A., Arora, S. \& Singh, A. 2015. Effect of domestic processing treatments on iron, $\beta$-carotene, phytic acid and polyphenols of pearl millet. Cogent Food \& Agri., 1(1): 1-12.

Sridevi, B.Y., N., R.R., H. \& P.W., B. 2011. Antioxidant contents of whole grain cereals, millets and their milled fractions. J. Dairying, Foods \& Home Sci., 30(3): 191-196.

Swain, T. \& Hillis, W. 1959. The phenolic constituents of Prunusdomestica. I. The quantitative analysis of phenolic constituents. J. Sci. Food and Agri., 10(1): 63-68.

Thilagavathi, T., Kanchana, S., Banumathi, P., Hemalatha, G., Vanniarajan, C., Sundar, M. \& Ilamaran, M. 2015. Physicochemical and functional characteristics of selected millets and pulses. Indian J. Sci. Technol., 8(S7): 147-155.

Vats, P. \& Banerjee, U.C. 2004. Production studies\& catalytic properties of phytases (myo-inositolhexakis-phosphate phosphohydrolases): an overview. Enzyme and Microbial Technol., 35: 3-14.

Walter, M. \& Marchesan, E. 2011. Phenolic compounds and antioxidant activity of rice. Brazilian Arch. Biol. Technol., 54(2): 371-377.

\section{How to cite this article:}

Isha Kaushik and Raj Bala Grewal. 2017. Antinutrient and mineral content of thirteen different varieties of Pearl Millet locally grown in Haryana, India. Int.J.Curr.Microbiol.App.Sci. 6(5): 21362143. doi: https://doi.org/10.20546/ijcmas.2017.605.239 